\title{
DARI ILMU TAUHID/ILMU KALAM KE TEOLOGI: ANALISIS EPISTEMOLOGIS
}

\author{
Syafii \\ IAIN Walisongo Semarang \\ imamsa_fii@yahoo.com
}

\begin{abstract}
Artikel ini membahas tentang paradigma baru dalam kajian ilmu tauhid dan ilmu kalam ke arah teologi dengan mengusung berbagai kepentingan kehidupan manusia di era kekinian. Kajian yang ada dalam ilmu tauhid dan ilmu kalam secara epistemologis dapat dijadikan sebagai modal keagamaan. Namun, dalam sejarahnya kajian yang ada menjadi sesuatu yang cenderung mengada-ada dan kurang menyentuh pada persoalan praktis umat manusia. Apa yang digagas oleh ulama terdahulu merupakan respon kesejarahan dan konsekuensi logis terhadap kebutuhan umat saat itu. Pergeseran epistemologis merupakan suatu keharusan dan mutlak dilakukan untuk menjadikan keagamaan manusia lebih segar dan dinamis.
\end{abstract}

Kata Kunci: ilmu tauhid, ilmu kalam, teologi, paradigma baru

\section{PENDAHULUAN}

Islam sebagai agama (din) mempunyai dua dimensi, yaitu keyakinan ('aqidah) dan sesuatu yang diamalkan. Amal perbuatan merupakan perpanjangan dan implementasi dari 'aqidah tersebut. Islam adalah agama samawi yang bersumber dari Allah swt., yang diwahyukan kepada Nabi Muhammad saw. yang berintikan keimanan dan perbuatan. Untuk alasan ini, Muhammad Syaltout menulis al-Islam 'Aqidah wa Syari'ah yang membahas pentingnya dua dimensi 'aqidah dan Syari'ah dalam ajaran Islam. ${ }^{1}$

Dalam sejarah peradaban Islam, paling tidak ada empat ilmu yang perkembangannya sangat berpengaruh satu dengan yang lain, yakni Ilmu Fiqh yang membahas masalah hukum dalam peribadatan dan kemasyarakatan; 
Ilmu Kalam, yang membicarakan tentang Tuhan beserta derivasinya; Tasawuf membahas penghayatan kepada keberadaan Tuhan dan cara untuk memperolehnya secara maksimal; dan Falsafah yang merupakan telaah spekulatif yang mendasar tentang segala masalah, terutama tentang hidup dan lingkungannya. ${ }^{2}$

Keimanan dalam Islam merupakan dasar atau pondasi, yang di atasnya berdiri syariat Islam. Antara keimanan dan perbuatan atau 'aqidah dan Syari'ahkeduanya sambung menyambung, tidak dapat dipisahkan antara yang satu dengan yang lain sebagaimana pohon dan buahnya. Keimanan atau 'aqidah dalam dunia keilmuan (Islam) dijabarkan dalam suatu disiplin ilmu yang sering diistilahkan dengan Ilmu Tauhid, Ilmu 'Aqa>'id, Ilmu Kalam, Ilmu Ushuluddin, Ilmu Hakikat, Ilmu Makrifat, dan sebagainya. Sementara dimensi lain menyangkut syariah dimuat dalam ilmu hukum Islam yang terdiri atas syariah dan fikih.

Problem kekinian muncul seiring dengan kebutuhan manusia dalam kehidupan keseharian untuk hidup yang lebih nyaman. Kebutuhan adanya sebuah idiologi yang jelas di tengah-tengah pertarungan global antara berbagai idiologi, pentingnya teologi baru ini bukan semata pada sisi teoritisnya, melainkan juga terletak kepada kepentingan praktis untuk secara nyata mewujudkan idiologi sebagai gerakan dalam sejarah, salah satu kepentingan praksis idiologi Islam (dalam teologi) adalah memecahkan kemiskinan dan keterbelakangan di negara-negara muslim dan kepentingan teologi yang bersifat praksis, yaitu secara nyata diwujudkan dalam realitas melalui realisasi tauhid dalam dunia Islam. ${ }^{3}$

Artikel ini akan membahas tentang persoalan ilmu tauhid atau ilmu kalam dan teologi secara epistemologis. Pembahasan akan dilakukan dengan merujuk bangunan epistemology ilmu tauhid dan ilmu kalam dan bangunan teologi dalam konteks kekinian. Apa yang dikaji dna dibahas ini diharapkan mampu memberikan jawaban real dari kebutuhan manusia di era sekarang dengan menjadikan kehidupan kesehariannya bermakna dan dilandasi fondasi keberagamaan. Secara tidak langsung akan dijadikan upaya internalisasi ajaran agama dalam kehidupan keseharian. Tentu, kebahagiaan abadi akan menjadi tuuan utama terutama dikaitkan dengan kehidupan manusia secara umum.

\section{ILMU TAUHID DAN ILMU KALAM}

Istilah ilmu Tauhid berasal dari bahasa Arab. Secara harfiah, tauhid ialah mempersatukan berasal dari kata wahid yang berarti satu. Menurut istilah agama Islam, Tauhid ialah keyakinan tentang satu atau Esanya Tuhan 
dan segala pikiran dan teori berikut dalil-dalilnya yang menjurus kepada kesimpulan bahwa Tuhan itu satu, disebut Ilmu Tauhid. Di dalamnya termasuk soal-soal kepercayaan dalam agama Islam. ${ }^{4}$ Kepercayaan itu disebut dengan rukun iman yang jumlahnya ada enam macam.

Syekh Muhammad Abduh mendefenisikan Ilmu Tauhid ialah Ilmu yang membahas tentang wujud Allah, sifat-sifat yang wajib bagi-Nya, sifatsifat yang jaiz yang disifatkan kepada-Nya, dan sifat-sifat yang sama sekali wajib ditiadakan dari-Nya (mustahil). Juga membahas tentang Rasul-rasul Allah untuk menetapkan kebenaran risalahnya, apa yang wajib ada pada dirinya, hal-hal yang jaiz dihubungkan (dinisbatkan) pada diri mereka dan halhal yang terlarang menghubungkanya pada diri mereka. ${ }^{5}$

Ilmu Tauhid adalah ilmu yang memberikan bekal-bekal pengertian tentang pedoman keyakinan hidup manusia, di dalam mengarungi samudra dan gelombang hidup. Secara kodrati manusia diciptakan Allah di dunia ini, berkekuatan berbeda antara manusia yang satu dengan manusia yang lain. Tidak sedikit manusia di dalam mengarungi samudera hidup yang luas itu, kehilangan arah dan pedoman, sehingga ia menjadi sesat. Di situlah ilmu Tauhid berperan untuk memberi pedoman dan arah, agar manusia selalu tetap sadar akan kewajibanya sebagai makhluk terhadap khaliknya.

Mempelajari Ilmu Tauhid sebagai ilmu yang mempelajari pokok-pokok agama yang sangat penting itu hukumnya wajib. Sebab dengan mempelajari Ilmu Tauhid kita akan mengetahui yang baik dan yang buruk, maka yang baik itu harus dijadikan pedoman dalam keyakinan dan beri tikad dan yang buruk ditinggalkan. Setelah umat manusia memeluk berbagai macam dasar kepercayaan dan menganut bermacam-macam faham (isme), kemudian mereka berpecah-pecah dan saling bermusuh-musuhan, maka Allah mengetahui akan kemaslahatan para hamban-Nya, menurunkan perintah-Nya kepada pesuruh-Nya yaitu Nabi Muhammad saw. Perintah suci itu telah disampaikan kepada seluruh umat manusia di muka bumi ini, baik kepada bangsa Arab atau bangsa lain dengan segala kebijaksanaan. Allah memerintahkan supaya para hamba-Nya memeluk agama Islam dan bertauhid kepada Allah. Menghabiskan seluruh hidupnya untuk meyakini dan mematuhi ajaran agama Islam yang sempurna.

Mempelajari ilmu tauhid biasanya didorong oleh keinganan untuk mengetahui lebih banyak dan lebih mendalam pengertian tentang Tuhan. Sebelum itu orang sudah memilki kepercayaan (Iman) kepada Tuhan, tetapi masih hanya secara samar-samar. Hal itu disebabkan karena memang setiap manusia lahir dengan membawa benih Iman dalam jiwanya. ${ }^{6}$

Kalau Tauhid sudah masuk dan meresap ke dalam jiwa seseorang, 
maka akan tumbuhlah dalam jiwa perasaan rela atas pemberian Allah untuk dirinya mengenai rezeki kedudukan dan lain-lain, rasa harga diri dan menghargai orang lain, sebab orang bertauhid memandang semua manusia sama derajat, berasal dari satu keturunan dan tidak ada yang berhak di pertuan atau di perhamba, rasa kasih saayang terhadap sesama manusia. Orang bertauhid memandang semua manusia bersaudara, umat yang bertauhid itu hidup berdasar peri kemanusiaan dan persaudaraan, selalu bersikap terbuka, kerjasama dan gotong-royong.

Sepanjang sejarah agama-agama wahyu, Ilmu Tauhid yang digunakan untuk menetapkan dan menerangkan segala apa yang diwahyukan Allah kepada Rasul-Nya tumbuh bersama tumbuhnya agama ini. Para tokoh agama berusaha memelihara dan meneguhkan agama dengan berbagai macam cara dan dalil yang mampu mereka ketengahkan. Ada yang kuat, ada yang sempit, ada yang luas, sesuai dengan masa dan tempat serta hal-hal yang mempengaruhi perkembangan agama. Perkembangan Ilmu Tauhid mengalami beberapa tahapan sesuai dengan sesuai dengan perkembangan Islam, yang dimulai pada masa Rasulullah saw., ${ }^{7}$ masa Khullafaurrasyidun, ${ }^{8}$ masa Daulah Umayyah, ${ }^{9}$ masa Daulah Abbasyiah $^{10}$ dan masa sesudah kemunduran Daulah Abbasyiah. ${ }^{11}$

Adapun kehadiran Ilmu kalam dalam sejarahnya dipicu oleh persoalan politik yang menyangkut peristiwa pembunuhan 'Ustman bin affan yang berbuntut pada penolakan Mu'awiyyah atas kekhalifahan Ali bin Abi Thalib. Ketegangan antara Mu'awiyyah dan Ali bin Abi Thalib mengkristal menjadi perang siffin yang berakhir dengan keputusan tahkim (arbitrase). Sikap Ali yang menerima tipu muslihat Amr bin Al-Ash, utusan dari pihak Mu'awiyyah dalam tahkim, sungguhpun dalam keadaan terpaksa, tidak disetujui oleh sebagian tentaranya. ${ }^{12}$

Mereka berpendapat bahwa persoalan yang terjadi saat itu tidak dapat diputuskan melalui tahkim. Putusan hanya datang dari Allah dengan kembali kepada hukum-hukum yang ada dalam al-Qur'an. La hukma illa lillah (tidak ada hukum selain dari hukum Allah) atau La hukma illa Allah (tidak ada perantara selain Allah) menjadi semboyan mereka. Mereka memandang Ali bin Abi Thalib telah berbuat salah sehingga mereka meninggalkan barisannya. Dalam sejarah Islam, mereka terkenal dengan nama Khawarij, yaitu orang yang keluar dan memisahkan diri atau secerders.

Senada dengan hal tersebut, T.M. Hasbi Ash-Shiddieqy menyebutkan alasan disebutnya ilmu tauhid dengan nama ilmu kalam, yaitu problema yang diperselisihkan para ulama dalam ilmu ini yang menyebabkan umat Islam terpecah kedalam beberapa golongan adalah masalah kalam Allah atau al- 
Qur'an; apakah ia diciptakan (makhluk) atau tidak (qadim), materi-materi ilmu ini ialah teori-teori (kalam); tidak ada yang diwujudkan ke dalam kenyataan atau diamalkan dengan anggota, ilmu ini, di dalam menerangkan cara atau jalan menetapkan dalil pokok-pokok akidah serupa dengan ilmu mantik. Ulama-ulama mutaakhirin membicarakan di dalam ilmu ini hal-hal yang tidak dibicarakan oleh ulama salaf, seperti penakwilan ayat-ayat mutasyabihat, pembahasan tentang qada, kalam dan lain-lain.

Perkataan Kalam berarti pembicaraan; yang dimaksud adalah pembicaraan dengan menggunakan nalar yang mendalam. Ini merupakan padanan dari istilah Yunani logos yang juga berarti pembicaraan. Dari perkataan logos diturunkan istilah logika, yang berarti nalar yang teratur. Dalam logika Yunani sangat dikenal rumusan Silogisme (logika formal) yang disusun oleh Aristoteles. Ilmu logika formal ini kemudian diterjemahkan ke dalam bahasa Arab dan dikenal sebagai Ilmu Manthiq. ${ }^{13}$

Dengan demikian mudah dipahami bahwa Ilmu Kalam, bersama-sama dengan Falsafah banyak menggunakan manthiq sebagai cara pendekatannya. Sesuai dengan isi bahasannya, Ilmu Kalam disebut pula dengan beberapa nama lain, yaitu Ilmu Aqa'id (ilmu tentang simpul-simpul kepercayaan, Ilmu Tauhid (ilmu tentang ke-Esaan Allah), dan Ilmu Ushuluddin (ilmu tentang pokok-pokok agama). ${ }^{14}$

Di Indonesia dan kawasan Asia Tenggara pada umumnya, Ilmu Kalam yang berkembang luas adalah yang diajarkan oleh Asy'ariyah. Sifat dua puluh adalah sesuatu yang khas Asy'ariyah yang dikenal oleh banyak orang. Ini disebabkan umat Islam di kawasan ini berfaham Ahlu as- Sunnah wal Jama $>$ 'ah sedangkan Al-Asy'ari merupakan tokoh penting dari golongan ini di bidang Ilmu Kalam.

Ilmu Kalam belum dikenal ketika Nabi Muhammad saw. masih hidup. Proses pengkajian agama berlangsung terus setelah Rasul wafat, sehingga muncul beberapa ilmu yang setelah menjadi besar kemudian memecah menjadi cabang-cabang yang lebih sempit tetapi kajiannya semakin mendalam. Ilmu Kalam sebagai disiplin ilmu yang berdiri sendiri terwujud pada masa Khalifah Al Ma'mun (wafat $218 \mathrm{H}$ ). Sebelum itu ilmu tersebut termasuk dalam Fiqh.

Ilmu Kalam ini kemudian mencakup beberapa obyek pembahasan. Yang pertama adalah kepercayaan terhadap Allah di dalam segala seginya, termasuk wujud-Nya, keesaan-Nya, dan sifat-sifat-Nya. Yang kedua, hubungan antara Allah dengan alam semesta, yang mencakup kekuasaan Allah, proses penciptaan alam, pengaturan Allah terhadap alam, penciptaan serta kedudukan malaikat dan jin. Yang ketiga adalah hubungan Allah secara 
khusus dengan manusia, yang mencakup keadilan dan kebijaksanaan Allah, kasih sayang Allah, keadilan Allah, pengutusan Rasul-rasul dan wahyu yang diturunkan kepada mereka, hari Kiamat dan pemeriksaan atas semua sikap dan perilaku setiap orang, pembalasan Allah atas perbuatan baik dan buruk yang dilakukan manusia selama hidup di dunia. ${ }^{15}$

Nama-nama yang dapat dinisbatkan pada Ilmu Tauhid/ilmu kalam adalah Ilmu Aqa>'id atau Aqa>'d a-'ilm. Aqa'id artinya ilmu ikatan kepercayaan (kebundelaning tekad $=$ jawa). Karena dalam pengetahuan ini ada pasal-pasal yang harus diikat, dibutuhkan erat-erat dalam hati kita yang harus menjadi kepercayaan yang teguh. Selain itu, dapat disebut juga dengan Ilmu Ushuluddin. Ilmu Ushuluddin adalah ilmu yang membahas pokok agama. Dinamakan demikian karena objek pembahasan utamanya adalah dasar-dasar agama yang merupakan masalah esensial dalam ajaran Islam. Masalah kepercayaan itu betul-betul menjadi dasar pokok lain dalam agama Islam. ${ }^{16}$ Nama lain juga ditemukan yaitu Ilmu Hakikat dan ilmu makrifat. Ilmu hakikat adalah Ilmu sejati, karena ilmu ini menjelaskan hakikat segala sesuatu, sehingga dapat meyakini akan keercayaan yang benar (hakiki). Adapun istilah Ilmu Ma'rifat karena dengan pengetahuan ini dapat mengetahui benarbenar akan Allah dan segala sifat-sifat-Nya dan dengan keyakinan yang teguh. $^{17}$

Istilah ilmu tauhid/ilmu kalam

\begin{tabular}{|l|l|}
\hline Nama & Pengertian \\
\hline Ilmu tauhid & Ilmu tentang ke-Esaan Allah \\
\hline Ilmu kalam & $\begin{array}{l}\text { Ilmu tauhid yang dibingkai } \\
\text { dalam kajian filsafat }\end{array}$ \\
\hline $\begin{array}{l}\text { Ilmu Aqa }>\text { 'id } \text { atau Aqa }>\text { 'id } \\
\text { al- } \text { ilm }\end{array}$ & Ilmu ikatan kepercayaan \\
\hline Ilmu Ushuluddin & Pokok-pokok agama \\
\hline Ilmu Hakikat & Ilmu sejati \\
\hline Ilmu makrifat & Pengetahuan \\
\hline
\end{tabular}

Meskipun nama yang diberikan berbeda-beda, inti pokok pembahasan Ilmu Tauhid adalah sama, yaitu Wujud Allah SWT. Aspek terpenting dalam Ilmu Tauhid ialah keyakinan akan adanya Allah Yang Maha Sempurna dan Mahakuasa. Keyakinan ini pada giliranya akan membawa kepada keyakinan terhadap adanya Malaikat, Kitab-kitab, Nabi dan Rasul, Hari Akhir dan melahirkan kesadaran akan tugas dan kewajiban terhadap khalik (pencipta). 


\section{PARADIGMA BARU TEOLOGI}

Istilah teologi bukan barasal dari tradisi Islam. Dalam Islam, istilah tersebut lebih dikenal dengan sebutan ilmu tauhid dan ilmu kalam. Atau variasi lain sebagaimana diungkap dalam pembahasan sebelumnya. Disebutkan dalam Kamus Besar Bahasa Indonesia, ${ }^{18}$ pengertian dari teologi adalah ilmu yang membicarakan tuhan atau pengetahuan ketuhanan. Theologia yang berasal dari bahasa latin dan bahasa grik tua, terdiri dari dua kata theo dan logia. Theo (theos jamaknya) dalam mitologi roma adalah pamanggilan bagi dewata dan para dewa.

Adapun kata theos itu dalam ajaran setiap agama adalah panggilan untuk kodrat-kodrat samawi yang berada di bawah kekuasaan tuhan, dan setiap agama mempunyai panggilan-panggilan tersendiri terhadap kodratkodrat samawi itu misalnya "malaikat" (agama Islam), "angelos" (agama Kristen), "mallak" (agama Yahudi), "ahuras" (agama Zarathusra), "daivas" (agama Hindu), dan "boddhisatvas" (agama Buddha) dan seterusnya. Kata logia yang dalam bahasa grik tua berasal dari kata logos (akal) berarti ajaran pokok (doctrin) atau teori (theory) atau ilmu (science). ${ }^{19}$

Ilmu Tauhid secara umum diartikan dengan ilmu yang membicarakan tentang cara-cara menetapkan aqidah agama dengan menggunakan dalil-dalil yang meyakinkan, baik dalil naqli, dalil aqli maupun dalil perasaan (wujdan). Sarjana barat menterjemahkan Ilmu Tauhid ke bahasa mereka dengan "Theologi Islam". Secara etimologi "Theologi" itu terdiri dari dua kata yaitu "theos" berarti "Tuhan" dan "Legos" berarti ilmu. Dengan demikian dapat diartikan sebagai ILMU KETUHANAN. Sedangkan secara terminologi (istilah), theologi itu diartikan: ${ }^{20}$

1. "The discipline which concert God or Devene Reality and Gods Relation to the world", maksudnya suatu pemikiran manusia secara sistematis yang berhubungan alam semesta.

2. "Sciense of religion, dealing therefore with God and Man in his relation to God", maksudnya pengetahuan tantang agama yang karenanya membicarakan tentang Tuhan dan Manusia serta manusia dalam hubungannya dengan Tuhan.

3. "The sciense which treats of the facts and fenomena of religion and the relationship between God and Man", maksudnya ilmu yang membahas fakta-fakta dan gejala agama dan hubungannya antara Tuhan dan Manusia.

Dari beberapa pengertian di atas dapatlah disimpulkan bahwa theologi itu merupakan ilmu yang membicarakan tentang Tuhan dan hubungannya 
dengan manusia, baik berdasarkan kebenaran agama (wahyu) ataupun berdasarkan penyelidikan akal murni. Inilah sebabnya theologi itu bukan hanya berupa uraian bersifat pikiran tentang agama semata (the intelectual expression of religion) tetapi dapat juga bercorak agama (reaviled theologi) or (filosophical theologi). Untuk itu siapa saja bisa menyelidiki sesuatu agama dengan semangat penyelidikan bebas tanpa harus dari orang-orang yang beragama tersebut atau mempunya hubungan dengan agama yang ditelitinya.

Ranah kajian teologi sebagaimana tergambar dari penjelasan di atas adalah sama dengan apa yang dikaji dalam tradisi Islam, ilmu tauhid dan Ilmu Kalam. Ilmu kalam mengalami perkembangan yang pesat, kajian atas ilmu kalam tidak hanya membahas seputar tentang ketuhanan ${ }^{21}$ semata melainkan telah ke ranah kehidupan manusia. Apalagi di era sekarang, yang mengharuskan manusia mampu survive di era global dengan tanpa meninggalkan jaket keislamannnya. Rekonstruksi teologi Islam (ilmu Kalam) agar teologi Islam benar-benar menjadi ilmu yang bermanfaat bagi manusia dan umat masa kini. $^{22}$

Namun, apakah istilah teologi dan ilmu kalam merupakan istilah yang pararel yang dapat dijadikan subtitusi keilmuan? Hal ini masih menimbulkan berbagai perbincangan. Konsep yang diusung oleh teologi agaknya berbeda dengan konsep ilmu kalam klasik. Padanan lain yang bias diartikulasikan dengan teologi adalah fiqih bukan ilmu kalam atau ilmu tauhid. Istilah fiqih dari sisi bukan menggambarkan obyek kajian yang ada di fiqih yakni hukum, melainkan merupakan awal lahirnya disiplin fiqih sebagaimana kajian yang dilakukan oleh Abu Hanifah. ${ }^{23}$

Beliau menulis tentang al-fiqh al-akbar yang isinya bukan tentang ilmu fiqih, tapi justru tentang aqidah yang menjadi obyek bahasan ilmu kalam atau tauhid. Boleh jadi, ilmu fiqih seperti yang berkembang sekarang ini dalam kerangka pemikiran Imam Abu Hanifah adalah al-fiqh al-asgar. Hal ini disebabkan oleh antara ilmu kalam atau ilmu tauhid dengan ilmu fiqih pada dasarnya adalah fiqih atau pemahaman yang tersistematisasikan. Yang pertama, menyangkut bidang ushuliyah (tentang yang prinsip atau yang pokok), sedangkan yang kedua menyangkut bidang furu'iyah (detail atau cabang). Akan tetapi perjalanan sejarah dan tradisi keilmuan Islam telah menyingkirkan pengertian fiqih sebagaimana dipergunakan Imam Abu Hanifah.

Teologi sebagai suatu disiplin ilmu yang membicarakan tentang "Tuhan" dalam tradisi keilmuan Islam terhitung sangat baru sekali. Ilmu ini dipopulerkan di Indonesia sejak Harun Nasution memasukkannya menjadi mata kuliah di Institut Agama Islam Negeri (IAIN) sejak tahun 1975. Berbeda 
dengan ilmu Tauhid, yang hanya mengajarkan cara bertuhan atau cara beriman menurut satu model atau satu aliran pemikiran saja, yang oleh seorang guru Tauhid saat itu di pandang sebagai doktrin, tetapi Teologi, mengajarkan banyak cara menuju Tuhan. Artinya dalam ilmu ini diajarkan berbagai aliran atau mazhab yang membicarakan Tuhan atau membicarakan bagaimana Tuhan berhubungan dengan manusia, menurut persepsi manusia. Dan tentu saja seorang guru yang mengajarkan ilmu ini harus menjadi liberal sekaligus plural dalam arti bahwa ia tidak dapat mengindoktrinasi bahwa aliran atau mazhab yang satu adalah benar, sementara aliran pemikiran atau mazhab yang lainnya adalah salah. Apa yang dilakukan Harun Nasution, bapak rasionalis Indonesia merupakan upaya untuk memahami Islam secara lebih utuh dan lebih integral. ${ }^{24}$

Namun ada juga yang tidak setuju tentang penerjemahan tersebut, Ilmu Kalam diterjemahkan sebagai teologi, dengan tujuan memudahkan orang yang terbiasa membaca literatur Barat. Terjemahan ini tidak tepat benar, karena teologi pada umumnya membahas semua bidang ajaran agama, sedangkan Ilmu Kalam hanya membahas dengan analisis rasional, pemahaman tentang Tuhan beserta konsekuensi bagi yang meyakini eksistensinya. ${ }^{25}$ Walaupun demikian, apa yang digagas patut untuk dipertimbangkan dalam rangka menjadikan perkembangan ilmu pengetahuan dalam Islam berkebang dinamis. Sudah selayaknya, perkembangan ilmu pengetahuan menjadikan manusia semakin bahagia dan terpenuhi kebutuhannya.

\section{SHIFTING PARADIGM DARI KALAM/TAUHID KE TEOLOGI}

Pembacaan ulang secara kritis terhadap tradisi Islam klasik (turas) sudah banyak dimunculkan dan disuarakan oleh para pemikir kontemporer Islam. Kebutuhan empiris kontemporer sangat memerlukan jawaban daripada berkutat wacana pemahaman berdasarkan teks kitab suci yang cenderung melangit. ${ }^{26}$ Mereka itu antara lain Hasan Hanafi, ${ }^{27}$ dan sebagainya. Upaya pembacaan ulang ini dilatarbelakangi oleh khazanah klasik tidak lagi dapat melakukan sinkronisasi antara turas dengan dinamika keilmuan dan modernitas pada umumnya. Atau dengan kata lain pemikiran Islam klasik out of date dan tidak adaptif lagi terhadap dinamika perkembangan ilmu. Ilmu kalam dan tauhid cenderung metafisis spekulatif atau apologis defensive dan selaras dengan penempatan hal ini dengan klasifikasi ilmu oleh Ibn Khaldun abad ke-9 dalam ilmu-ilmu agama. ${ }^{28}$ Oleh sebab itu perlu adanya perubahan paradigma dalam memahami keilmuan klasik. Dalam konteks artikel ini adalah ilmu kalam dan ilmu tauhid.

Shifting paradigm dalam kerangka berfikir disiplin Islamic studies 
harus berubah dari pengakuan adanya permanent logic ke pangakuan dan apresiasi terhadap new logic dengan cara komitmen untuk salah dan menerima kritik. Method of science bisa salah sehingga perlu koreksi terus menerus. Perlunya memajukan studi agama dengan melakukan kajian kritik, comparative, katalogisasai, sistematisasi dan mau keluar dari zona believe serta menggunakan pendekatan etik (outsider perspective) guna memperoleh gambaran umum tentang religion general pattern.

Gagasan di atas dalam kajian filsafat ilmu merupakan adopsi dari teori revolusi ilmu pengetahuan yang dikembangkan oleh Thomas Kuhn. Kritik Kuhn terhadap teori verifikasi dan konfirmasi eksperimental yang dikembangkan Lingkaran Wina (Vienna Circle) ${ }^{29}$, serta kritiknya terhadap teori Karl Popper tentang falsifiabilitas (the tesis of refutability) ${ }^{30}$ menjadi awal revolusi ilmu pengetahuan Kuhn. Adanya perkembangan ilmu pengetahuan ditandai oleh sebuah pergeseran paradigma (shifting paradigm). Persoalan tersebut dimunculkan oleh Thomas Kuhn dalam karya monumentalnyayang berjudul The Structure of Scientific Revolution.

Apa yang dikaji dalam ilmu tauhid dan kalam adalah menyangkut persoalan tentang ketuhanan dan kemudian dibingkai dengan kajian filsafat. Sebagaimana dijelaskan dalam pembahasan sebelumnya, maka posisi ilmu tauhid adalah cenderung dalam konteks pemahaman teks sebagaimana yang diungkapkan dalam al-Qur'an dan Hadis. Adanya jarak yang terlalu lebar antara "teori" dan "praksis" dalam kajian kalam, antara "idealitas" dan "relitas", antara "teks" dan "konteks".

Seiring dengan problem masyarakat kontemporer yang menjadikan keyakinan sebagai sesuatu yang penting dan kajian yang dilakukan dalam ilmu kalam dan tauhid tidak banyak yang dapat dilakukan lagi karena cenderung berupaya memahami antara teks dan kehendak Tuhan semata. Jadi tradisi keilmuan yang dibangun pada masa itu telah melampaui kehendak dan kebutuhan masyarakat sekarang. Perubahan kehendak masyarakat yang menjadikan bumi yang satu-satunya agar dapat secara nyaman untuk dihuni memerlukan pijakan teologis dalam konteks penyelamatan manusia secara keseluruhan. Bukankan dalam al-Qur'an dijelaskan tentang orang yang berupaya membuat kehidupan yang baik akan menjadikan kehidupan manusia secara keseluruhan. Demikian juga sebaliknya, yang menjadikan kesempitan dalam kehidupan maka akan terjadilah kemunduran kemanusiaan yang mengakibatkan kematian. Upaya ini bukan merupakan sesuatu yang baru. Banyak tokoh yang sudah memulainya, antara lain Amin Syukur, ${ }^{31}$ atau pemikir komtemporer lainnya seperti Farid Essack, Asghar Ali Engineer, dan sebagainya. 
Upaya ini secara tidak langsung adalah untuk menghindari tidak terselesaianya persoalan kemanusiaan yang semakin kompleks di era kekinian. Kebutuhan akan kehidupan manusia yang lebih sesuai dengan fakta di lapangan dan tidak hanya menghayal dalam konteks pemikiran semata. Seperti persoalan eksatologis, selayaknya dimaknai dalam konteks kemanusiaan di muka bumi dan bukan hanya dalam konteks kehidupan di akhirat yang akan datang. Spiritual kajian kalam dan tauhid seharusnya dijadikan pijakan dalam mencapai kebahagiaan manusia. Apalagi di saat persoalan kehidupan semakin kompleks dengan jumlah manusia 7 milyar dan minimnya sumber daya alam dengan banyaknya bencana dan eksploitasi yang dapat meminimkan potensi kemanusiaan.

\section{KESIMPULAN}

Dari pembahasan sebelumnya dapat disimpulkan bahwa perlu adanya pemaknaan ulang dalam diskursus epistemology tauhid/kalam ke teologi yang sifatnya berkaitan deangan manusia secara langsung. Keyakinan seseorang dalam menjalankan pengabdiannya kepada Tuhan tidaklah membutuhkan diskursus keilmuan yang rumit sebagaimana yang berkembang dalam sejarah ilmu tersebut. Seiring dengan problem msyarakat dan manusia di era sekarang sangat memungkinkan menjadikan pola teologi menjadi alternative penyelesaian secara bijak, seperti bencana, ekonomi hijau (green economy), lingkungan hidup dan sebangainya.[]

\section{Catatan Akhir}

${ }^{1}$ Lihat Mahmud Syaltut, al-Isla>m 'aqidah wa Syari'ah(Tp: Darul Qalam, 1966).

${ }^{2}$ Lihat Wahiduddin Khan, Kritik terhadap Ilmu Fiqih, Tasauf dan Ilmu Kalam (Jakarta: GIP, 1994), h. 61.

${ }^{3}$ Lih. Hassan Hanafi, Teologi Islam: Aliran-Aliran, Sejarah, Analisa, Perbandingan (Jakarta: Penerbit Universitas, 2000).

${ }^{4}$ Antara lain seperti Tauhid uluhiyah, ubudiyah dan sebaginya, Lih. Daud Rasyid, Islam dalam Berbagai Dimensi, (Jakarta: GIP, 2000), h. 1-23

${ }^{5}$ Ibid., h. 2.

${ }^{6}$ Lihat Sunan Abu Dawud No. 4091 dalam CD Mawsuat al-Hadis al-Syarif.

${ }^{7}$ Lihat Masa Rasulullah saw merupakan periode pembinaan aqidah dan peraturanperaturan dengan prinsip kesatuan umatan kedaulatan Islam. Harun Nasution, Teologi Islam (Jakarta: UI Press, 1983), h. 15. 
${ }^{8}$ Lihat masa permulaan khalifah Islam khususnya khalifah pertama dan kedua, Ilmu Tauhid masih tetap seperti masa Rasulullah saw. Hal ini disebabkan kaum muslimin tidak sempat membahas dasar-dasar aqidah dimaksud. Namun pada masa Usman bin Affan, mulai timbul kekacauan yang berbau politik dan fitnah, sehingga Usman sendiri terbunuh. Lihat Salihun A. Nasir, Ilmu Kalam: Pengertian, Sejarah dan Perkembangan (Surabaya: Bina Ilmu, 1980), h. 20.

${ }^{9}$ Lihat dalam masa ini kedaulatan Islam bertambah kuat sehingga kaum muslimin tidak perlu lagi berusaha untuk mempertahankan Islam seperti masa seebelumnya. Kesempatan ini digunakan kaum muslimin untuk mengembangkan pengetahuan dan pengertian tentang ajaran Islam. Qadariyah, Jabariyah, Mazhab mu'tazilah, dan lain-lain. Lihat A. Hanafi, Teologi Islam (Jakarta: Bulan Bintang, 1982), h. 13.

${ }^{10}$ Lihat Masa ini merupakan zaman keemasan dan kecemerlangan Islam, ketika terjadi hubungan pergaulan dengan suku-suku di luar arab yang mempercepat berkembangnya ilmu pengetahuan. Usaha terkenal masa tersebut adalah penterjemahan besar-besaran segala buku Filsafat. Salihun A. Nasir, Ilmu Kalam: Pengertian, Sejarah dan ..., h. 30 .

${ }^{11}$ Lihat Sesudah kemunduran Daulah Abbasyiah, golongan asy'ariyah yang sudah terlalu jauh menggunakan filsafat dalam alirannya tidak banyak mendapat tantangan lagi. Hanya sedikit mendapat reaksi dari golongan Hambaliyah yang tetap berpegang pada pandangan golongan Salaf, beriman dengan apa yang sudah disebutkan al-Quran dan Hadits Rasulullah saw tanpa memerlukan takwil. Pada abad ke delapan Hijriah muncullah Ibnu Taimiyah menentang aliran Asy'ariyah, karena terlalu berlebihan menggunakan filsafat dalam pembahasan Ilmu Tauhid. Timbullah pro dan kontra, ada yang membenarkan Ibnu Taimiyah dan ada yang menganggapnya sesat. Usaha Ibnu Taimiyah ini dilanjutkan oleh muridnya Ibnu Qaiyim al-Jauziyah. Sesudah itu pembahasan Ilmu Tauhid terhenti. Lihat A. Hanafi, Teologi Islam..., h. 36.

${ }^{12}$ Lihat Murtadha Mutahhari, Mengenal Ilmu Kalam terj. Ilyas Hasan (Jakarta: Pustaka Zahrah, 2002), lahirnya kalam, h. 15-24.

${ }^{13}$ Lihat M. Abdul Mujib dkk., Ensiklopedi Ilmu Tasauf al-Gazali (Bandung: Hikmah Mizan Group, 2009), h. 190-192.

${ }^{14}$ Lihat Murtadha Mutahhari, Mengenal Ilmu Kalam terj. Ilyas Hasan (Jakarta: Pustaka Zahrah, 2002), h. 26-27

${ }^{15}$ Lihat Tsuroya Kiswati, Al-Juwaini Peletak Dasar Rasional Teologi dalam Islam (Jakarta: Erlangga, 2006), h. 41-60.

${ }^{16}$ Lihat Kamarul Shukri Mohd Teh, Pengantar Ilmu Tauhid (Selangor: Dar Ehsan, 2008), Nama-nama, h. 1-2

${ }^{17}$ Ibid.

${ }^{18}$ Lihat http://bahasa.kemdiknas.go.id/kbbi/index.php

${ }^{19}$ Lihat Syamsuddin Arif, Orientalis dan DIabolisme Pemikiran (Jakarta: GIP, 2008), h. $46-47$.

${ }^{20}$ Ibid.

${ }^{21}$ Tradisi ilmu kalam dimaknai dengan ilmu yang membincangkan akidah (keyakinan) dengan menggunakan dalil yang meyakinkan. Lihat http://majdah.maktoob.com/vb/majdah26752/ diakses tanggal 30 September 2011. 
${ }^{22}$ Menurut Hasan hanafi, untuk melakukan rekonstruksi teologi sekurang kurangnya dilatar belakangi oleh tiga hal, sebagai berikut: kebutuhan akan adanya sebuah idiologi yang jelas di tengah-tengah pertarungan global antara berbagai Idiologi, pentingnya teologi baru ini bukan semata pada sisi teoritisnya, melainkan juga terletak kepada kepentingan praktis untuk secara nyata mewujudkan idiologi sebagai gerakan dalam sejarah, salah satu kepentingan praksis idiologi Islam (dalam teologi) adalah memecahkan kemiskinan dan keterbelakangan di negara-negara muslim dan kepentingan teologi yang bersifat praksis, yaitu secara nyata diwujudkan dalam realitas melalui realisasi tauhid dalam dunia Islam. Lihat Hassan Hanafi, dari Teosentrimes Ke Antroposentrisme, terj. Team IKIS (Yogyakarta: IKIS, 2004).

${ }^{23}$ Lihat Michael Cook, Commanding Right and Forbidding Wrong in Islaic Thought (Cambridge: University Press, 2000), h. 307-334.

${ }^{24}$ Lihat Amin Syukur, "Paradigma Baru Ilmu Kalam" dalam Amin Syukur, dkk (et.al), Teologi Islam Terapan, Upaya Antisipatif Terhadap Hedonisme Kehidupan Modern (Klaten: Tiga Serangkai, 2003), 20-23. surge tidak hanya di akhrat tapi dunia juga.

${ }^{25}$ Lihat M. Amin Abdullah: "Kajian Ilmu Kalam Di IAIN Menyongsong Perguliran Paradigma Keilmuan Keislaman Pada Era Milenium Ketiga" dalam Al-Jami'ah, Journal of Islamis Studies, No 65, (Yogyakarta: IAIN Sunan Kalijaga, 2000), h. 84-85.

${ }^{26}$ Murphy. Nancey. Theology in The Age of Scientific Reasoning (Ithaca and London: Cornell University Press, 1990), h. 87.

${ }^{27}$ Lihat Hassan Hanafi: "From Dogma o Revolution", yang isinya merupakan resume karyanya, Minal 'aqidah ila al-Tsauroh, Muhawalah li I'adat Bina i al-'Ilm Ushul al-Diin, h. 5

${ }^{28}$ Lihat Baidhowi, Antropologi al-Qur'an (Yogyakarta: IKIS, 2008), 68. Lihat juga Wahiduddin Khan, Kritik terhadap Ilmu Fiqih, Tasauf dan Ilmu Kalam (Jakarta: GIP, 1994), h. 61.

${ }^{29}$ K. Bertens, Filsafat Barat Abad XX, (Jakarta: Gramedia, 1983), h. 75.

${ }^{30}$ Lihat Karl Popper, Conjectures and Refutation, The Growth of Scinetific Knowledge, (London: Routledge and Kegan Paul, 1974), h. 193.

${ }^{31}$ Lihat Amin Syukur, "Paradigma, h 15-22. 


\section{DAFTAR PUSTAKA}

Abdullah , M. Amin, "Kajian Ilmu Kalam Di IAIN Menyongsong Perguliran Paradigma Keilmuan Keislaman Pada Era Milenium Ketiga" dalam Al-Jami'ah, Journal of Islamis Studies, No 65, Yogyakarta: IAIN Sunan Kalijaga, 2000.

Baidhowi, Antropologi al-Qur'an (Yogyakarta: IKIS, 2008), 68. Lihat juga Wahiduddin Khan, Kritik terhadap Ilmu Fiqih, Tasauf dan Ilmu Kalam. (Jakarta: GIP, 1994).

Bertens, K., Filsafat Barat Abad XX, (Jakarta: Gramedia, 1983).

Cook, Michael, Commanding Right and Forbidding Wrong in Islaic Thought. (Cambridge: University Press, 2000).

Hanafi, A., Teologi Islam. (Jakarta: Bulan Bintang, 1982).

Hanafi, Hassan, Dari Teosentrimes Ke Antroposentrisme, terj. Team IKIS (Yogyakarta: 1KIS, 2004.

Hanafi, Hassan, Teologi Islam: Aliran-Aliran, Sejarah, Analisa, Perbandingan (Jakarta: Penerbit Universitas, 2000).

http://bahasa.kemdiknas.go.id/kbbi/index.php

http://majdah.maktoob.com/vb/majdah26752/ diakses tanggal 30 September 2011.

Khan, Wahiduddin, Kritik terhadap Ilmu Fiqih, Tasauf dan Ilmu Kalam, (Jakarta: GIP, 1994).

Kiswati, Tsuroya, Al-Juwaini Peletak Dasar Rasional Teologi dalam Islam, (Jakarta: Erlangga, 2006).

M. Abdul Mujib dkk., Ensiklopedi Ilmu Tasauf al-Gazali, (Bandung: Hikmah Mizan Group, 2009).

Mohd Teh, Kamarul Shukri, Pengantar Ilmu Tauhid (Selangor: Dar Ehsan, 2008).

Murphy. Nancey, Theology in The Age of Scientific Reasoning, (Ithaca and London: Cornell University Press, 1990).

Mutahhari, Murtadha, Mengenal Ilmu Kalam, terj. Ilyas Hasan, (Jakarta: Pustaka Zahrah, 2002).

Nasir, Salihun A, Ilmu Kalam: Pengertian, Sejarah dan Perkembangan, (Surabaya: Bina Ilmu, 1980).

Nasution,Harun, Teologi Islam, (Jakarta: UI Press, 1983). 
Popper, Karl, Conjectures and Refutation, The Growth of Scinetific Knowledge, (London: Routledge and Kegan Paul, 1974).

Rasyid, Daud, Islam dalam Berbagai Dimensi, (Jakarta: GIP, 2000).

Sunan Abu Dawud No. 4091 dalam CD Mawsuat al-Hadis al-Syarif.

Syaltu $>$ t, Mah $\}$ mu $>$ d, al-Isla $>m$ 'aqidah wa Syari> 'ah, (Darul Qalam: 1966).

Syukur, Amin, "Paradigma Baru Ilmu Kalam", dalam Amin Syukur, dkk (et.al), Teologi Islam Terapan, Upaya Antisipatif terhadap Hedonisme Kehidupan Modern, (Klaten: Tiga Serangkai, 2003). 